Bu makaleye atıfta bulunmak için/To cite this article:

ZINDEREN, A. (2021). YouTube Ortamındaki Haberciliği Haritalandırmak: Gazetecilerin YouTube Haber Kanallar

Üzerine Tanımlayıcı Bir Çalıșma. Atatürk Üniversitesi Sosyal Bilimler Enstitüsü Dergisi, 25 (3), 932-950.

\title{
YouTube Ortamındaki Haberciliği Haritalandırmak: Gazetecilerin YouTube Haber Kanalları Üzerine Tanımlayıcı Bir Çalışma
}

Aslihan ZINDEREN (*)

Öz: YouTube'un giderek büyüyen bir sosyal ă̆ olması; haber yayıncılı̆̆ının bu ortama taşınması ve YouTube haber kanallarına her geçen gün yenilerinin eklenmesi sonucunu doğurmaktadır. Bu çalı̧̧manın amacı bireysel olarak gazeteciler tarafindan açılan ve YouTube ortamında aktifiçerik üretiminde bulunan YouTube haber kanallarına ilişkin bir çerçeve çizmektir. $B u$ amaç doğrultusunda içerik analizi yöntemine başvurulmuş ve araştırma soruları ekseninde kategoriler oluşturulmuştur. Oluşturulan kategoriler bağlamında "Etkin içerik üretiminde bulunan bireysel YouTube haber kanalı sayısı kaçtır?, Bu kanal sahipleri kimlerdir?, Hakkında sekmesinde kendilerini nasıl tanımliyorlar?, Kanalların hesap doğrulaması var mı?, Kanalların açıllş ve içerik üretimine başladıkları tarih, abone, video ve kanal görüntüleme sayıları, içerik üretme sıklı̆ğ, yayın süresi, ağıllkklı içerik türü, video içerik özellikleri, yayıncılık biçimleri, kullanıcı etkileşimi nasıldır?, Yıllık tahmini kazanç ne kadardır?, En fazla izlenen ve en fazla yorum yapılan videoların konusu ve türü nedir?" sorularına yanıt aranmaktadır. Analizler sonucu gazetecilerin YouTube ortamındaki habercilik faaliyetleri haritalandırılmıştır.

Anahtar Kelimeler: Yeni medya, Youtube, gazeteci, haber

\section{Mapping Journalism in the YouTube Environment: A Descriptive Study of Journalists' YouTube News Channels}

Abstract: YouTube is a growing social network; this results in the transfer of news broadcasting to this environment and the addition of new ones to YouTube news channels every day. The aim of this study was to draw a framework for YouTube news channels, which are opened by individual journalists and produce active content on YouTube. For this purpose, content analysis method was applied, and categories on the axis of the research questions were created. In the context of the categories created, answers to questions like "How many individual YouTube news channels are active in producing content?, Who are these channel owners?, How do they describe themselves in the about us section of the channel?. Do the channels have account verification?, How are the date of the channels opening and content production, subscriber, video and channel, the number of views, frequency of content production, broadcast duration, weighted content type, video content features, publishing formats, user interaction?, What are the estimated annual earnings?, What is the subject and type of the videos with the most views and comments?" were sought. As a result of the analysis, the reporting activities of the journalists in the YouTube environment were mapped.

Keywords: New media, YouTube, journalist, news

Makale Geliş Tarihi: 06.07.2021

Makale Kabul Tarihi: 23.09.2021

DOI: $10.53487 /$ ataunisosbil.963024

*) Dr. Öğr. Üyesi, Atatürk Üniversitesi İletişim Fakültesi Gazetecilik Bölümü (e-posta: aslihan.cezik@atauni.edu.tr) (D) ORCID ID. https://orcid.org/0000-0001-6761-4160

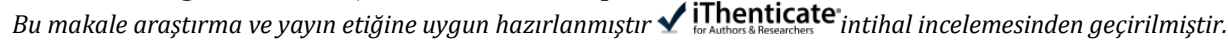




\section{Giriş}

İletişim teknolojilerindeki gelişmelerle birlikte çok sayıda yeni yayıncılık platformu ortaya çıkmıştır. Bu platformlar farklı dijital araç ve ortamlarla uyumluysa ve bu doğrultuda içerik üretimi, paylaşımı, dağıtımı ve kullanıcı ile etkileşim gibi konularda kullanım kolaylığı sağlıyorsa kullanıcı sayılarını her geçen gün arttırmaktadır. YouTube, aktif içerik üreten kanalların ve izleyici sayısının hızla arttığı dijital bir platformdur. Kullanıcısına kendi kanalını kurma ve gelir elde etme olanağı, istenilen zaman ve sürede video paylaşımı, canlı yayın, hikâye paylaşımı ve kullanıcı ile etkileşim gibi olanaklar sunan YouTube, içerik çeşitliliği açısından oldukça önemli bir kaynak niteliği taşımaktadır.

YouTube sıradan kullanıcının şöhreti yakaladığı, sesini diğerlerine duyurduğu, maddi kazanç elde edebildiği, kişinin kendi video günlüğünü oluşturduğu bir ortama işaret etmektedir. Bununla birlikte YouTube'un giderek popüler bir platform haline gelmesi geleneksel yayıncılık yapan kurumların ve kişilerin de bu ortamda varlık göstermesi sonucunu doğurmuştur. TV kanallarının, radyoların ve gazetelerin büyük bir çoğunluğunun YouTube kanalı mevcuttur. Ayrıca geleneksel medyada popüler olan kişileri de YouTube yayıncılığı yaparken görmek mümkündür. Dolayısıyla YouTube geleneksel olanla da iç içe geçmiş bir platform olma özelliği taşımaktadır.

YouTube'da sayısı giderek artan içerik türlerinden biri de haberdir. YouTube ortamında habercilik faaliyetleri günden güne çeşitlenmektedir. Televizyon haber kanalları, ajanslar, gazeteler, dijital haber kanalları ve gazeteciler tarafindan açılan haber kanalları YouTube ortamında habercilik faaliyeti gerçekleştirmektedir. YouTube'un alternatif bir yayıncılık platformu olması, canlı yayın olanağı sunması ve yayın kaydının kolayca alınması, kullanıcı etkileşimi, çeşitli üyelik seçeneklerinin ortaya çıkması, diğer sosyal medya kanalları ile entegre olması, kolay dağıtım imkânı sunması gibi pek çok özellik habercilik açısından büyük kolaylık sağlamaktadır. Dolayısıyla YouTube ortamındaki habercilik her geçen gün daha önemli hale gelmektedir.

Çalışmanın amacı, gazeteciler tarafından bireysel olarak açılmış ve aktif olarak içerik üreten YouTube haber kanallarını tanımlayarak gazetecilerin YouTube ortamındaki habercilik faaliyetlerine yönelik bir çerçeve çizmektir. Bu kapsamda çalışmada gazeteciler tarafindan açılmış etkin içerik üretiminde bulunan bireysel YouTube haber kanallarına odaklanılmakta ve şu sorulara yanıt aranmaktadır:

- Gazeteciler tarafindan açılmış ve etkin içerik üretiminde bulunan bireysel YouTube haber kanalı sayısı kaçtır?

- $\quad$ Bu yayıncılar kimlerdir? Geleneksel medya ile ilişkileri nasıldır?

- Bu kanallar kendilerini nasıl tanımlamaktadır?

- Kanalların açılış ve içerik üretimine başladıkları tarih nedir?

- Bu kanalların abone sayıları, video sayıları, kanal görüntülenme sayıları, yayın sıklığı, yayın süreleri, yıllık tahmini kazancı nasıldır?

- Kanalların hesap doğrulaması var mıdır?

- Kanallarda katıl butonu aktif midir? Bu kanalların izleyicileri ile kurdukları iletişim nasıldır? 
YouTube Ortamındaki Haberciliği Haritalandırmak: Gazetecilerin YouTube Haber Kanalları Üzerine Tanımlayıcı Bir Çalıșma

- Bu kanalların kategorileri ve ağırlıklı içerikleri nelerdir?

- Bu kanalların yayıncılık biçimleri nasıldır?

- Bu kanalların video içerik özellikleri nasıldır?

- Bu kanallarda en fazla izlenen videonun haber konusu ve türü nedir?

- Bu kanallarda en fazla yorum yapılan videonun haber konusu ve türü nedir?

Bu soruların yanıtlarına ulaşmak için içerik analizi yöntemi kullanılmakta ve sorular kategorilere dönüştürülerek tablolar oluşturulmaktadır. Tablolarda yer alan veriler analiz edilerek ve çapraz karşılaştırmalar yapılarak anlamlı sonuçlara ulaşılmaya çalışılmaktadır. Çalışmanın yöntem kısmından önce yeni medya ve gazetecilik araştırmalarına dair bir çerçeve çizmek için alanyazın taramasına yer verilmektedir. Daha sonra YouTube ve YouTube ortamındaki habercilik üzerinde durulmuştur. Çalışma, YouTube ortamındaki habercilik pratiklerini gazeteciler çerçevesinde değerlendirmesi bakımından önemlidir.

\section{Alanyazın}

Yeni medya ortamındaki gazetecilik pratiklerine yönelik pek çok çalışma mevcuttur. $\mathrm{Bu}$ çalışmaların büyük bir bölümü yeni iletişim ortamı ve teknolojilerinin gazeteciliğe etkileri üzerinde yoğunlaşmaktadır. Ayrıca birçok çalışma yeni medya ortamındaki değişimlerin gazeteciliğe nasıl tesir ettiği konusuna eğilmektedir. Yeni medya ortamındaki gazetecilik pratikleri pek çok farklı şekilde isimlendirilmektedir. İnternet gazeteciliği, online gazetecilik, sanal gazetecilik, dijital gazetecilik ya da platformlar özelinde sosyal medya gazeteciliği veya ortaya çıkan yeni gazetecilik biçimleri bağlamında mobil gazetecilik, yurttaş gazeteciliği, veri gazeteciliği gibi haber yapma biçimlerine ilişkin tartışmalar temelde yeni medya ortamındaki habercilik ile ilgilidir.

Yeni medya ve habercilik üzerine yapılan öncü çalışmalar yoğun olarak geleneksel medya ile yeni medya ortamını karşılaştırmakta ve gazeteciliği ortaya çıkan farklılıklar noktasında değerlendirmektedir (Heinonen, 1999; Pavlik, 2001; Bardoel ve Deuze, 2001; Çevikel, 2004; Gürcan (ty.); O'sullivan ve Heinonen, 2008; Korkmaz, 2009; Bulunmaz, 2011; Yurdigül ve Zinderen, 2012; Öztermiyeci, 2017). Bununla birlikte söZ konusu farklılıklar haber değerlerinden, gazeteci-okur ilişkisine, gazetecinin görev ve sorumluluklarından haber odalarındaki değişime kadar geniş bir yelpazede ele alınmaktadır.

Yeni medya ve gazetecilik açısından üzerinde sıklıkla durulan konuların başında haber etiği gelmektedir. Yapılan çalışmalarda yeni medya ortamındaki haberciliğin ortaya çıkardığı etik sorunlar bağlamında; hız, haber-reklam ayrımının ortadan kalkması, görüntü ile oynama, manipülasyon, dezenformasyon, izinsiz kaynak kullanımı, kopyalayapıştır habercilik, tık odaklı habercilik, tekrara dayalı haber metinleri gibi hususlar üzerinde durulmaktadır (Deuze ve Yeshua, 2001; Çaplı, 2002; Birsen, 2005; Geray ve Aydoğan, 2010; Umur ve Koz 2014; Friend ve Singer, 2015; Tandoc Jr. ve Thomas, 2015; Duman, 2018; Benkler, Faris ve Roberts, 2018; İşliyen, 2021; Buadit ve Laophairot, 2021). Dijital ortamdaki haber etiği tartışmaları ilk zamanlardan bugüne ortaya çıkan yeni sorunların da eklemlenmesi ile güncelliğini korumaktadır. 
Alanyazına bakıldığında yeni medya ve gazetecilik açısından ortaya çıkan güncel tartışmaların yoğun olarak alternatif medya (Holt, Ustad Figenschou ve Frischlich, 2019; Nygaard, 2019; Dağtaş ve Şirvanlı, 2020), sosyal medya haberciliği (Chan, 2017; Demir ve Ayhan, 2020; Mesutoğlu, 2020) ve özellikle de haber-okur ilişkisi (Çevikel, 2015; Fletcher ve Nielsen, 2018; He, Han, Mukherjee, Obradovic ve Dragut, 2020) çerçevesinde genişlediği görülmektedir. Elbette bu konular arasında keskin bir sınır çizmek mümkün değildir. Bu çalışmanın konusunu oluşturan YouTube ortamındaki habercilik gerek alternatif yayıncılık açısından, gerek sosyal medya haberciliği bağlamında, gerekse haber-okur ilişkisi ekseninde ele alınabilir.

YouTube haberciliğine yönelik alanyazın taraması yapıldığında çalışmaların çoğunda doğrudan YouTube ortamındaki haberciliğe odaklanılmadığı, bu konunun daha çok sosyal medya haberciliği veya alternatif habercilik adı altında tartışıldığı görülmektedir (Antony ve Thomas, 2010; Poel ve Borra, 2012; Paulussen ve Harder, 2014; Kıyan ve Törenli, 2018). Diğer taraftan doğrudan YouTube ortamındaki haberciliğe odaklanan çalışmalar da bulunmaktadır. Bu çalışmaların birçoğunda içerik analizi yöntemi kullanılmıştır. Peer ve Ksiazek, 2011 yılında yayınladıkları 'Youtube and The Challenge to Journalism: New Standards for News Videos Online' isimli çalışmalarında YouTube'daki haber videolarını incelemiş ve geleneksel formdan uzaklaşan, sosyal medya ortamına uygun olarak üretilen videoların daha fazla görüntüleme aldığından söz etmiştir. Djerf-Pierre, Lindgren ve Budinski (2019) 'The role of journalism on YouTube: audience engagement with" Superbug" reporting' adlı çalışmalarında YouTube'da gazeteciliğin rolü üzerinde durmuştur. Bulut, 2020 yılında yaptığı 'Yazılı Basın Sınır Ötesinde: İçeriğin Kâğıttan Videoya Dönüşümü ve Gazetelerin Youtube Platformundaki Habercilik Deneyimleri' isimli çalışmasında basılı gazetelerin YouTube ortamındaki habercilik pratiklerine odaklanmıştır. Bulut, yine aynı yıl yayınladığı 'Egemen Söylemin Kıyısındakiler: Alternatif Bir Platform Olarak YouTube'da Gazetecilik ve Gazeteciler Üzerine Bir İnceleme' isimli çalışmasında ise YouTube ortamındaki haberciliği alternatif medya çerçevesinde ele almış ve gazeteciler üzerinden değerlendirmiştir. 2021 yılında yayınlanan 'Ulusal Gazetelerin Bir Haber Mecrası Olarak YouTube'u Kullanma Biçimlerinin İncelenmesi' isimli çalışması ile İpek, ulusal gazeteleri YouTube'daki habercilik faaliyetleri çerçevesinde incelemiştir.

\section{YouTube ve YouTube Ortamında Habercilik}

YouTube, kullanıcıların diğer kullanıcılar tarafından oluşturulan videoları ücretsiz olarak paylaştığı ve görüntülediği bir video paylaşım sitesidir (Chau, 2010). YouTube, hakkımızda bölümünde kendisini "misyonumuz, herkese sesini duyurma ve dünyayı tanıma şansı vermektir" ifadesi ile tanımlamaktadır. "Değerlerimiz, bizi biz yapan dört temel özgürlüğe dayanıyor" diyen YouTube, bu dört temel özgürlük ilkesini ifade özgürlüğü, bilgi edinme özgürlüğü, fırsat özgürlüğü ve aidiyet özgürlüğü olarak ifade etmektedir (YouTube, 2021).

İlk olarak 2005 yılında kullanıcı tarafından oluşturulan içeriğe odaklanarak başlatılan YouTube, dünya çapında çevrimiçi video için baskın bir platform olmuştur. Çağdaş yeni medya ortamındaki en önemli eğilimlerin ve tartışmalarınsa odağında yer almaya 
YouTube Ortamındaki Haberciliği Haritalandırmak: Gazetecilerin YouTube Haber Kanalları Üzerine Tanımlayıcı Bir Çalışma

başlamıştır. YouTube kısa tarihi boyunca yeni medyanın siyaseti, ekonomisi ve kültürleri ile ilgili bilimsel tartışmaların, özellikle de "Web 2.0" iş modelleri ile ilişkilendirilen "katılımcı dönüşüm”ün odak noktası haline gelmiştir (Burgess, 2011: 1).

YouTube, içerik paylaşmak ve yayınlamak için çevrimiçi bir platformdan çok daha fazlasıdır. Teknik ve sosyal özellikleri, topluluğunun üyeleri arasında katılımcı bir kültürün oluşumunu desteklemektedir (Chau, 2010). Katılımcı kültür, medya çalışmaları çerçevesinde geniş bir yelpazede ele alınabilecek bir konudur. Bununla birlikte YouTube katılımcı kültürü, sunduğu teknik özellikleri yoluyla teşvik etmektedir. YouTube çerçevesinde katılımcılık, kendi içeriğini üretip paylaşma, var olan bir içeriğin dağıtımında aracı olma, beğenme, beğenmeme, yorum yapma, yanıt verme ve katıl butonu ile ücret ödeyerek bağlılık rozeti elde etme gibi bir takım özellikler çerçevesinde ortaya çıkmaktadır.

YouTube kullanıcı sayısı dünya genelinde her geçen gün artmaktadır. Bu artış bir yandan kanal artışı bir yandan da izleyici artışıdır. We Are Social ve Hootsuite'in Dijital 2020 raporuna bakıldığında Türkiye'de en fazla kullanılan sosyal medya platformunun YouTube olduğu görülmektedir.

Güncel istatistikler çerçevesinde We Are Social ve Hootsuite ortaklığıyla yayınlanan 2021 yılı raporuna bakıldığında dünyanın büyük bir kısmının karantinada olduğu 2020 yılında sosyal medya kullanıcılarının sayısı son üç yılın en hızlı artışı ile 4.20 milyara ulaşmıştır. Rapora göre Türkiye'deki aktif sosyal medya kullanıcı sayısı ise 60 milyondur. Türkiye'de geçtiğimiz yıla göre aktif sosyal medya kullanıcı sayısında \% 11.1 (6 milyon) oranında artış görülmüştür (We are social ve Hootsuite, 2021). Bu artıştan payını alan sosyal medya platformlarının başında ise YouTube gelmektedir. We Are Social ve Hootsuite'in Dijital 2021 raporuna göre YouTube'a ilişkin bazı veriler:

- Her ay giriş yapmış durumdayken YouTube'u ziyaret eden kullanıcı sayısı 2 milyardır.

- Her gün YouTube'da toplamda 1 milyar saat video izlenmektedir.

- Insanların YouTube'da video izleyerek geçirdikleri ortalama süre geçtiğimiz yıla göre bazı ülkelerde 6 kata kadar artmıştır.

- Küresel düzeyde insanlar Android telefonlarında YouTube uygulamasını kullanarak ayda ortalama 23 saatten fazla zaman harcamaktadır. Bununla birlikte Google'ın kendi verileri, cep telefonlarının YouTube izlenme süresinin yalnızca yaklaşık yüzde 70'ini oluşturduğunu ortaya koymakta ve tüm cihazlardaki toplam sürenin ayda 33 saat civarında olduğunu göstermektedir.

YouTube'un giderek popüler bir platform haline gelmesinin bir sonucu olarak bünyesindeki kanal türleri de çeşitlenmektedir. YouTube'da artış gösteren kanal türlerinden biri de haber kanallarıdır. YouTube ortamındaki haber kanalları üç şekilde sinıflandırılabilir. Bunlardan ilki geleneksel yayıncılık yapan televizyon, gazete ve haber ajansları tarafından açılan YouTube haber kanallarıdır. Bu kanal türü genel olarak incelendiğinde YouTube yayıncılıklarının ilk zamanlarında, geleneksel yayın organları için ürettikleri içerikleri paylaştıkları dikkat çekmektedir. Fakat bugün bu kanalların 
çoğunda YouTube'a uygun ve özgün içeriklerin de üretildiği görülmektedir. İkincisi geleneksel yayıncılık yapmayan, doğrudan dijital olarak ortaya çıkan haber kanallarıdır. $\mathrm{Bu}$ kanallar genellikle birkaç kişinin ortaklığı ile kurulan ve çoğunlukla ortama uygun yayıncılık anlayışının benimsendiği kanallardır. Üçüncüsü ise bireysel olarak gazeteciler tarafından açılmış haber kanallarıdır. Bu kanal kurucularının birçoğunun uzun süre geleneksel yayın organlarında çalıştı̆̆ görülmektedir. Bu gazetecilerden bazıları büyük oranda YouTube ortamına uygun ve kendilerine özgü yayıncıllk biçimi sergilerken bir kısmı ortama özgü içerik üretmeyip geleneksel medyada yayınlanan içerikleri paylaşmaktadır.

\section{Yöntem}

Bu çalışmanın amacı bireysel olarak gazeteciler tarafından açılan ve bu ortamda etkin içerik üretiminde bulunan YouTube haber kanallarına ilişkin bir çerçeve çizmektir. Dolayısıyla YouTube ortamında aktif içerik üreten gazetecilerin YouTube'daki habercilik faaliyetleri haritalandırılmaktadır. Bu amaç doğrultusunda çalışmada içerik çözümlemesi yöntemine başvurulmuştur. "İçerik çözümlemesi iletişim içeriğinin, genellikle önceden belirlenmiş sınıflamalar (kategoriler) çerçevesinde sistematik olarak gerçekleştirilmesini sağlayan bir araştırma tekniğidir” (Geray, 2014: 135). İçerik çözümlemesi yöntemi, iletişim araştırmalarında en fazla sahiplik politikaları, gerçek dünya ile karşılaşıırma, temsil, medya etkisi araştırmalarına destek ve resmetme amacıyla kullanılmaktadır. Resmetme medyanın kişileri, kümeleri resmetme, desenlerinin veya eğilimlerin ortaya çıkarılması anlamına gelmektedir (Gunter'den aktaran Geray, 2014: 137). Araştırma yöntemi çerçevesinde araştırma soruları esas alınarak kategoriler oluşturulmuştur. Oluşturulan kategoriler ekseninde nicel ve nitel veriler sınıflandırılmış, haber kanalları söz konusu veriler ışığında karşılaştırılarak analiz edilmiştir.

Çalışmanın evrenini Türkiye'den yayın yapan gazetecilerin bireysel YouTube haber kanalları oluşturmaktadır. Çalışmanın amacı çerçevesinde haber temasını karşılayan, YouTube'a özgü içerik üreten, güncel konular üzerinden etkin ve düzenli olarak içerik üreten kanallar örnekleme dâhil edilmiş̧ir. Söz konusu kıstaslar üzerinden gerçekleştirilen detaylı taramalar sonucu örnekleme uyan toplam 10 YouTube haber kanalı olduğu görülmüştür.

Analiz kapsamında incelenecek YouTube haber kanalları belirlenirken YouTube ortamındaki habercilik faaliyetlerine ilişkin detaylı bir tarama yapılmıştır. Bu tarama YouTube, Social Blade, BoomSocial gibi detaylı sosyal medya verilerine ulaşılabilecek platformlarda gerçekleştirilmiş̧ir. Buna göre dünyanın en popüler video paylaşım platformu olan YouTube'da gerek haber kategorisinde, gerekse haberin dışında çeşitli içeriklere de sahip olması sebebiyle farklı kategorilerde görünen haber temalı birçok kanal bulunmaktadır. Özellikle Dokuz8 Haber, GZT ve İnternet Haber gibi haber siteleri ile Hürriyet, Habertürk ve Cumhuriyet gibi geleneksel medya organlarının da YouTube'da etkin içerik üretiminde bulundukları görülmektedir. Diğer yandan bireysel YouTube kanalları üzerinden haber ağıllıklı içerik üreterek gazetecilik faaliyetini bu platform üzerinden yürüten pek çok gazeteciden bahsetmek mümkündür. Ancak bu 
YouTube Ortamındaki Haberciliği Haritalandırmak: Gazetecilerin YouTube Haber Kanalları Üzerine Tanımlayıcı Bir Çalıșma

kanallar incelendiğinde hepsinin etkin ve düzenli bir içerik üretiminde bulunmadığ 1 görülmektedir. Bu doğrultuda İrfan Değirmenci, Hilal Kaplan, Levent Gültekin, Emin Çapa, Kemal Öztürk, Çağlar Cilara, Erkan Doğan ve Deniz Gez gibi gazetecilerin bir kısmı kanallarında etkin ve düzenli bir içerik üretiminde bulunmadığı; diğer bir kısmı ise tamamen veya ağırlıklı olarak televizyon kanallarındaki içerikleri bu platforma yüklediği için analizlerde kapsam dışı bırakılmıştır.

\section{Analiz ve Bulgular}

Çalışma kapsamında YouTube haber kanalları incelenen gazeteciler Tablo 1'de gösterilmektedir.

Tablo 1: Kanalları İncelenen Gazeteciler ve Erişim Adresleri*

\begin{tabular}{lll}
\cline { 2 - 3 } $\mathbf{1}$ & Gazetecinin Adı & \multicolumn{1}{c}{ YouTube Erişim Adresi } \\
\cline { 2 - 3 } $\mathbf{2}$ & Can Ataklı Özköse & $\underline{\text { https://www.youtube.com/c/Adem\%C3\%96zk\%C3\%B6se/ }}$ \\
\hline $\mathbf{3}$ & Cüneyt Özdemir & $\underline{\text { https://www.youtube.com/c/CanATAKLI1/ }}$ \\
\hline $\mathbf{4}$ & Mehmet Özışı & $\underline{\text { https://www.youtube.com/c/cuneytozdemir/ }}$ \\
\hline $\mathbf{5}$ & Murat Yetkin & $\underline{\text { https://www.youtube.com/channel/UCyBZcYSKPAPFypWCKoV6brg }}$ \\
\hline $\mathbf{6}$ & Nevşin Mengü & $\underline{\text { https://www.youtube.com/ch/Nev\%C5\%9FinMeng\%C3\%BCofficial }}$ \\
\hline $\mathbf{7}$ & Özlem Gürses & $\underline{\text { https://www.youtube.com/channel/UCojOP7HHZvM2nZz4Rwnd6-Q }}$ \\
\hline $\mathbf{8}$ & Ruşen Çakır & $\underline{\text { https://www.youtube.com/c/RusenCakirTR/ }}$ \\
\hline $\mathbf{9}$ & Timur Akkurt & $\underline{\text { https://www.youtube.com/c/TimurAkkurt1/ }}$ \\
\hline $\mathbf{1 0}$ & Ünsal Ünlü & $\underline{\text { https://www.youtube.com/channel/UCzJMy0X4vYivbZHkNccpPhQ }}$ \\
\hline *Alfabetik olarak siralanmıştır.
\end{tabular}

Gazete ve dergilere bağlı olarak gazetecilik yapan Adem Özköse 2019 yılında açtığ YouTube kanalında röportaj, belgesel ve yorum türünde içerik üreticisi olarak varlık göstermektedir. Gazetecilik mesleğini farklı gazete ve televizyonlarda sürdüren Can Ataklı 2018 yılında açtığı YouTube kanalında televizyon program videolarının yanı sıra son dönemde ağırlıklı olarak gündeme ilişkin yorum ve analizlere yer vermektedir. Çeşitli televizyon programlarına ve belgesellere imza atan Cüneyt Özdemir, CNN Türk ekranlarında hazırladığı ve sunduğu 5 N $1 \mathrm{~K}$ ile öne çıkmıştır. Son dönemde televizyon ekranları yerine 2010 yılında açtığı YouTube kanalında gündeme ilişkin içerik üretiminde bulunmaktadır. Daha önce farklı gazetelerde çalışan Mehmet Özışık, 2019 yılından itibaren YouTube kanalında gündeme ilişkin yorum ve analiz videoları hazırlamaktadır. Yerli ve yabancı birçok basın kuruluşuna bağlı olarak gazetecilik yapan Murat Yetkin, Yetkin Report adlı sitede blog haberciliğine başlamıştır. 2020 yılından itibaren de YouTube kanalında gündeme ilişkin yorum ve analiz videoları yayınlamaktadır. Gazetecilik mesleğinde farklı medya kuruluşlarında çalışan Nevşin Mengü, bir süre DW Türkçe YouTube kanalında program sunmuştur. 2020 yılından itibaren kendi kanalında gündem özetleri, yorum ve analiz türünde içerikler üretmekte ve canlı yayınlar yapmaktadır. Farklı televizyon kanallarında programlar yapan Özlem Gürses, 2020 yılından itibaren gündeme ilişkin yorum, analiz ve röportajlarını YouTube kanalında yayınlamaktadır. Çeşitli dergi ve gazetelerde meslek hayatını sürdüren Ruşen Çakır, 2015 yılında medyascope tv'yi kurmuş, burada YouTube ve podcast kanalları üzerinden siyaset ağırlıklı programlar yapmıştır. Medyascope bünyesinde sunduğu 
haber, söyleşi ve yorum temalı videoları kişisel YouTube kanalında yayınlayan Çakır, gazetecilik mesleğini bu platformlar üzerinden bağımsız olarak sürdürmektedir. Gazete, dergi ve radyo mecralarında teknoloji haberciliği üzerine yoğunlaşan Timur Akkurt, 2013 yılından itibaren kişisel YouTube kanalında teknoloji haberciliği başta olmak üzere farklı içeriklerde video yayınlamaktadır. Gazetecilik mesleğini farklı medya kuruluşlarında sürdüren Ünsal Ünlü 'patronsuz' bir gazetecilik için kişisel web sitesini, patreon platformunu ve 2015 yılından itibaren içerik üretmeye başladığı YouTube kanalını kullanmaktadır. Kanalında gazete haberlerini yorumlamakta, gündeme ilişkin yorum ve analizler yapmaktadır.

Görüldüğü gibi YouTube ortamında habercilik yapan gazetecilerin tamamı geleneksel medyadan gelmektedir. Gazetecilerin çoğu ise daha önce gazete ve televizyonda çalışmıştır. Bu gazetecilerin bir kısmı habercilik faaliyetini yalnızca YouTube üzerinde gerçekleştirirken bir kısmı aynı zamanda gazete ya da televizyonda çalışmayı sürdürmektedir.

Kanalların 'Hakkında' sekmesinde yer alan açıklama bölümüne bakıldığında Özdemir, Yetkin ve Ünlü dışında tüm diğer kanal sahiplerinin kendisini gazeteci olarak tanımladığı görülmektedir. Özellikle Gürses'in 'kadın', 'gazeteci' gibi ifadeler kullanması kanalın kimlik temsili açısından dikkate değerdir. Özışık, Özköse ve Akkurt mesleki geçmişlerini detaylı bir şekilde anlatırken Atakl, Ünlü ve Yetkin'in kendilerine ve kanala ilişkin bilgi vermedikleri görülmektedir. Mengü ve Çakır ise daha çok kanala ilişkin bilgi vermektedir. Özdemir ve Gürses ise kendilerini mesleki yaşamı dışında kısa ifadelerle tanıtmaktadır. Örneğin Özdemir' in kanalında yer alan ifade 'Özgür, Bağımsız, Kafasına Göre, Cesur, Komik, Son Derece Ciddi, Kafa Karıştıran, Eğlenceli, Ufuk Açan, Vizyon Katan Yorumlarıyla Cüneyt Özdemir'in Kişisel Youtube Sayfası' şeklindedir.

Tablo 1'de yer alan gazetecilerin YouTube haber kanalları araştırma soruları çerçevesinde oluşturulan kategoriler göz önünde bulundurularak incelenmiştir. Tablo 2 'de kanalların isimleri, hesap açılıs tarihleri ve ilk video yükledikleri tarihler yer almaktadır. Buna göre gazetecilerin haber kanallarında kendi isimlerini kullandıkları görülmektedir. Bu durumda iki unsurun etkili olduğu düşünülmektedir. Bunlardan ilki bu gazetecilerin geleneksel medyada yer alan ve belirli bir kesim tarafindan tanınan kişiler olması nedeniyle isimlerinin bir marka değeri taşıması, ikincisi ise zaten bilinen isimler olduğu için kanalın akılda kalıcılığını arttırarak YouTube aramasını kolaylaştırmaktır. Ayrıca YouTube'da kanal sahiplerinin kendi isimlerini kullanmaları genel bir eğilimdir.

Tablo 2: İncelenen Kanalların İsimleri, Hesap Açılış Tarihleri ve İçerik Üretimine Başladıkları Tarihler*

\begin{tabular}{llcc}
\hline \multicolumn{1}{c}{ Gazetecinin Adı } & \multicolumn{1}{c}{ Kanal Adı } & Hesap Açılıs Tarihi & Video İçerik Üretim Tarihi \\
\hline Cüneyt Özdemir & Cüneyt Özdemir & 13.12 .2010 & 14.12 .2010 \\
\hline Timur Akkurt & Timur Akkurt & 28.3 .2012 & 7.1 .2013 \\
\hline Ruşen Çakır & Rusen Cakir medyascope & 3.9 .2012 & 22.5 .2015 \\
\hline Nevşin Mengü & Nevşin Mengü & 22.1 .2013 & 14.7 .2020 \\
\hline Ünsal Ünlü & Ünsal Ünlü & 5.4 .2014 & 26.8 .2015 \\
\hline
\end{tabular}


YouTube Ortamındaki Haberciliği Haritalandırmak: Gazetecilerin YouTube Haber Kanalları Üzerine Tanımlayıcı Bir Çalışma

\begin{tabular}{llcc}
\hline Özlem Gürses & Özlem Gürses & 27.4 .2017 & 27.3 .2020 \\
\hline Can Ataklı & Can Ataklı̈ & 27.4 .2018 & 25.10 .2018 \\
\hline Mehmet Özıșık & Mehmet Özışık & 14.11 .2018 & 28.8 .2019 \\
\hline Adem Özköse & Adem Özköse & 19.5 .2019 & 22.25 .2019 \\
\hline Murat Yetkin & Murat Yetkin & 28.3 .2020 & 7.4 .2020 \\
\hline
\end{tabular}

*Hesap açılış tarihine göre sıralanmıştır.

Kanalların açılış tarihi ile ilk video yükledikleri tarihler karşılaştırıldığında 6 gazetecinin kanallarını açtıktan uzun bir süre sonra içerik üretimine başladıkları görülmektedir. Bu kanallar içerisinde en dikkat çekici olan ise açılışından 7,5 yıl sonra içerik üreten Nevşin Mengü'nün kanalıdır. Bu durum aslında 6 gazeteci ekseninde ilk olarak bir haber kanalı oluşturma fikirlerinin olmadığ kanal açtıklarını göstermektedir. Dolaysıyla bu durum YouTube'un popüler hale gelmesi, kullanıcı sayısındaki hızlı artış, YouTube'a eklenen yeni özellikler, kişisel haber kanalı örneklerinin ortaya çıkması ve büyük medya kuruluşlarının dışında bağımsız habercilik faaliyeti yürütmek gibi bir takım hususların gazetecileri YouTube ortamında içerik üretimine teşvik etmiş olabileceği şeklinde yorumlanabilir. Bununla birlikte YouTube'un gazeteciler için daha bağımsız hareket etme olanağı sunması, geleneksel medyada yer bulamayan içeriklere yer verilebilmesi, abonelik, katıl butonu gibi özellikleri ile kullanıcı etkileşiminin üst düzeyde olması ve YouTube'da içerik üretiminin yeni bir iş modeli olarak ortaya çıkması gibi hususların gazetecilerin bu platforma yönelmelerinde etkili olduğu düşünülmektedir.

Tablo 3: İncelenen Kanalların Abone, Video ve Kanal Görüntüleme Sayıları*

\begin{tabular}{cccc}
\hline Gazetecinin Adı & Abone Sayısı & Video Sayısı & Kanal Görüntüleme Sayısı \\
\hline Cüneyt Özdemir & 1,24 Milyon & 2,198 & 256.302 .564 \\
\hline Nevşin Mengü & 312 Bin & 307 & 25.496 .738 \\
\hline Rușen Çakır & 173 Bin & 3,083 & 50.940 .580 \\
\hline Can Atakıı & 139 Bin & 433 & 16.451 .189 \\
\hline Ünsal Ünlü & 130 Bin & 2,696 & 23.502 .280 \\
\hline Özlem Gürses & 105 Bin & 314 & 9.576 .786 \\
\hline Timur Akkurt & 88,5 Bin & 251 & 18.079 .983 \\
\hline Murat Yetkin & 67,3 Bin & 151 & 4.974 .598 \\
\hline Adem Özköse & 59,9 Bin & 169 & 4.893 .741 \\
\hline Mehmet Özışı & 38,6 Bin & 320 & 5.608 .912
\end{tabular}

*Abone sayılarına göre sıralanmıştır.

Tablo 3'de analiz edilen kanalların abone, video ve kanal görüntülemelerine ilişkin nicel verileri yer almaktadır. Buna göre en fazla abonesi olan gazeteci 1,24 Milyon ile Cüneyt Özdemir'dir. Bu kanalın abone sayısı diğer kanallarla kıyaslandığında abone sayısına ilişkin aralığın son derece geniş olduğu görülmektedir. Elbette Özdemir'in abone sayısının diğer kanallara göre oldukça yüksek olmasında birçok faktör etkili olabilir. Bununla birlikte video içerik üretimi açısından en eski tarihli kanal olmasının da etkisi olduğu söylenebilir. Diğer taraftan Özdemir YouTube ortamında içerik üretimine ilk başlayan gazeteci olmasına rağmen video sayısı bakımından Ruşen Çakır ve Ünsal Ünlü'nün gerisindedir. Verilere göre en fazla video yayınlayan gazeteci Ruşen 
Çakır'dır. Bu doğrultuda video sayısı ile abonelik sayısı arasında doğrusal bir ilişkinin olmadığı görülmektedir. Tablo 3'deki veriler incelendiğinde abone sayısı ile kanal görüntüleme sayısı arasında da doğrusal bir ilişkinin olmadığı söylenebilir. Örneğin; abone sayısı bakımından ikinci sırada yer alan Nevşin Mengü'nün kanalı, kanal görüntüleme sayısı bakımından üçüncü sırada yer almaktadır. 173 bin abonesi olan Ruşen Çakır'ın kanalı 50.940.580 kez görüntülenerek Özdemir'in kanalından sonra en fazla görüntülenen kanal olmuştur. Abone ve kanal görüntüleme açısından ortaya çıkan fark, çok sayıda kişinin abone olmadan kanalda gezindiklerini göstermektedir. $\mathrm{Bu}$ noktada Çakır'ın izleyici kitlesi oluşturma noktasında zayıf kaldığı da çıkarılabilecek sonuçlardan biridir.

Tablo 4: İncelenen Kanalların İçerik Üretme Sıklığı, Hesap Doğrulaması ve Katıl Butonuna Dair Bilgileri İle Yıllık Tahmini Kazanca İliş̧in Verileri*

\begin{tabular}{lcccc}
\hline \multicolumn{1}{c}{ Gazetecinin Adı } & $\begin{array}{c}\text { İçerik Üretme } \\
\text { (Son 1 Hafta) }\end{array}$ & $\begin{array}{c}\text { Hesap } \\
\text { Doğrulaması }\end{array}$ & $\begin{array}{c}\text { Katıl } \\
\text { Butonu }\end{array}$ & Yıllık Tahmini Kazanç \\
\hline Cüneyt Özdemir & 12 & Var & Var & $\$ 36.8 \mathrm{~K}-\$ 588 \mathrm{~K}$ \\
\hline Ruşen Çakır & 11 & Yok & Var & $\$ 9.2 \mathrm{~K}-\$ 146.9 \mathrm{~K}$ \\
\hline Özlem Gürses & 10 & Yok & Yok & $\$ 3.1 \mathrm{~K}-\$ 49.9 \mathrm{~K}$ \\
\hline Ünsal Ünlü & 9 & Var & Var & $\$ 3 \mathrm{~K}-\$ 47.6 \mathrm{~K}$ \\
\hline Nevşin Mengü & 6 & Var & Var & $\$ 17.1 \mathrm{~K}-\$ 273.9 \mathrm{~K}$ \\
\hline Mehmet Özışık & 4 & Var & Var & $\$ 677-\$ 10.8 \mathrm{~K}$ \\
\hline Can Ataklı & 3 & Var & Var & $\$ 4.9 \mathrm{~K}-\$ 77.8 \mathrm{~K}$ \\
\hline Murat Yetkin & 3 & Yok & Var & $\$ 2.2 \mathrm{~K}-\$ 34.5 \mathrm{~K}$ \\
\hline Timur Akkurt & 2 & Yok & Yok & $\$ 260-\$ 4.2 \mathrm{~K}$ \\
\hline Adem Özköse & 1 & Yok & Var & $\$ 130-\$ 2.1 \mathrm{~K}$ \\
\hline *̇ंçerik üretme sıklı̆̆ına göre sıralanmıstır. & & &
\end{tabular}

*İçerik üretme sıklığına göre sıralanmıştır.

Tablo 4'de gazetecinin son bir haftada kaç video yayınladığı, kanalın hesap doğrulamasının ve katıl butonunun olup olmadığı ve yıllık tahmini kazançlarına yönelik istatistiklere yer verilmektedir. Buna göre son bir haftada 12 video ile en fazla video yayınlayan gazeteci Özdemir ilk sırada, Çakır 11 video ile ikinci sırada, Gürses 10 video ile üçüncü sırada yer almaktadır. Gürses'in ilk içerik üretimine 2020 yılında başladığ 1 göz önünde bulundurulursa mevcut video sayısı ve bir haftada ürettiği videolara bakılarak YouTube ortamında ciddi bir yer edinme çabasında olduğu söylenebilir. En az video yayınlayan gazeteciler Özköse ve Akkurt'tur. Söz konusu haber olduğunda haftada bir ya da iki videonun yayınlanması haber kanalı misyonu çerçevesinde yetersizdir.

Hesap doğrulama YouTube tarafından kanalın, söz konusu gazeteciye ait olduğunun doğrulanması ve kanala resmiyet kazandırılması anlamına gelmektedir. Bu durum ise sahte hesapların önüne geçilmesi noktasında önemlidir. Dolayısıyla hesap doğrulama, kanal güvenilirliği açısından oldukça önemlidir. Tablodaki verilere göre 5 kanalın hesabı doğrulanmıştır.

Katıl Butonu son zamanlarda ortaya çıkan, kanalın izleyici tarafından maddi olarak desteklenmesini sağlayan, kanal ile izleyici arasındaki bağı gösteren bir yeniliktir. Katıl butonunu etkinleştiren kişinin yorumlarda ve canlı sohbette adının yanında bağlılık rozetleri gösterilir. $\mathrm{Bu}$ bağlılık rozetleri ödenen ücrete göre farklı renklerde derecelendirilir. Bu durum kişiye kanal ekseninde bazı ayrıcalıklar (özel içerik, kanal ile 
YouTube Ortamındaki Haberciliği Haritalandırmak: Gazetecilerin YouTube Haber Kanalları Üzerine Tanımlayıcı Bir Çalışma

canlı sohbet, vb.) kazandırır. Katıl butonu aslında gazeteciye ekstra gelir sağlamaktadır. Katıl butonunun aktif hale getirilmesi için YouTube tarafından belirlenen bazı şartlar (örneğin kanalın YouTube İş Ortağı Programı üyesi olması) vardır. Tabloya baktığımızda çoğu gazetecinin katıl butonunu aktif hale getirdiği görülmektedir. Yalnızca Gürses ve Akkurt'un katıl butonu aktif değildir.

Tablo 4'te gazetecilerin yıllık tahmini kazançları dolar bazında gösterilmektedir. Burada çeşitli metrikler üzerinden hesaplanan para kazanma SocialBlade tahmini verilerine dayanmaktadır. Bu veriler video izlenme sayısı, süresi, reklam sıklığı gibi bir takım parametreleri kapsamaktadır. Tabloya göre en fazla gelir elde eden gazeteci Cüneyt Özdemir'dir. Bununla birlikte YouTube'dan gelir elde etme yalnızca video izlenme süresi ya da reklam aralığı gibi faktörlere bağlı değildir. Burada sponsorluk, ürün yerleştirme, ürün tanıtımı gibi bir takım faktörlerin de bulunduğu unutulmamalıdır. Ancak kazançlara ilişkin veriler YouTube'un gazeteciler için yeni bir iş kapısı olduğunun göstergesi niteliğindedir.

Tablo 5: İncelenen Kanalların En Kısa ve En Uzun Yayın Süreleri*

\begin{tabular}{lccl}
\hline Gazetecinin Adı & $\begin{array}{c}\text { En Kısa Yayın } \\
\text { Süresi }\end{array}$ & $\begin{array}{c}\text { En Uzun Yayın } \\
\text { Süresi }\end{array}$ & \multicolumn{1}{c}{ Süre Açıklamaları } \\
\hline Adem Özköse & $00: 04: 08$ & $01: 39: 22$ & $15 \mathrm{dk}$ ile $45 \mathrm{dk}$ arasındaki yayınları yoğunlukta \\
\hline Can Ataklı & $00: 01: 58$ & $01: 14: 14$ & $10 \mathrm{dk}$ ile $20 \mathrm{dk}$ arasındaki yayınları yoğunlukta \\
\hline Cüneyt Özdemir & $00: 03: 15$ & $03: 50: 30$ & Ortalama 60 dakikalık yayınları yoğunlukta \\
\hline Mehmet Özışı & $00: 04: 52$ & $01: 12: 48$ & $5 \mathrm{dk}$ ile $20 \mathrm{dk}$ arasındaki yayınları yoğunlukta \\
\hline Murat Yetkin & $00: 03: 38$ & $00: 54: 08$ & $10 \mathrm{dk}$ ile $20 \mathrm{dk}$ arasındaki yayınları yoğunlukta \\
\hline Nevşin Mengü & $00: 05: 11$ & $01: 15: 31$ & $30 \mathrm{dk}$ ile $50 \mathrm{dk}$ arasındaki yayınları yoğunlukta \\
\hline Özlem Gürses & $00: 02: 50$ & $01: 44: 43$ & $\begin{array}{l}10 \mathrm{dk} \text { ile } 50 \mathrm{dk} \text { arasında yoğunlukta ve diğerlerine göre } \\
\text { daha geniş yelpazede yayın sürelerine sahip }\end{array}$ \\
\hline Ruşen Çakır & $00: 08: 46$ & $01: 47: 23$ & 20 dk ile 50 dk arasındaki yayınları yoğunlukta \\
\hline Timur Akkurt & $00: 06: 44$ & $01: 38: 37$ & Çok değişken \\
\hline Ünsal Ünlü & $00: 10: 29$ & $01: 38: 43$ & 30 dk ile $60 \mathrm{dk}$ arasındaki yayınları yoğunlukta \\
\hline
\end{tabular}

*Alfabetik olarak sıralanmıştır.

Tablo 5'te kanalların yayın sürelerine dair veriler bulunmaktadır. Verilere göre yayın süreleri açısından bir standardın olmadığı görülmektedir. Bu durum ise standart bir süre ve programa bağlı kalınarak yapılan televizyon haberciliğinin dışında bir durumu göstermektedir. Dolayısıyla YouTube'da pek çok açıdan daha bağımsız olan gazeteci zaman sınırı açısından da daha özgürdür. Tabloya göre en uzun video süresine erişmiş olan kişi Özdemir'dir. Ayrıca Özdemir'in genel yayın süresi açısından diğer gazetecilere göre yayınları daha uzun sürmektedir.

Tablo 6: İncelenen Kanalların YouTube'da Yer Aldığg Kategoriler ve Ağırlıklı İçerikleri $^{1 *}$

\begin{tabular}{lcc}
\hline \multicolumn{1}{c}{ Gazetecinin Adı } & Kategori & Ăğırlıklı İçerik \\
\hline Adem Özköse & Haber & Gündem Haber Yorum (Uluslararası) \\
\hline Can Ataklı & Haber & Gündem Haber Yorum \\
\hline
\end{tabular}

${ }^{1}$ Social Blade üzerinden elde edilen bu sınıflandırma, kullanıcıların son 10 videosundan türetilen bir metriktir. 


\begin{tabular}{lcl}
\hline Cüneyt Özdemir & Haber & Gündem Haber Yorum \\
\hline Mehmet Özıșı & $\mathrm{X}$ & Gündem Haber Yorum \\
\hline Murat Yetkin & $\mathrm{X}$ & Gündem Haber Yorum \\
\hline Nevşin Mengü & Film & Gündem Haber Yorum \\
\hline Özlem Gürses & $\mathrm{X}$ & Gündem Haber Yorum \\
\hline Ruşen Çakır & Haber & Gündem Haber Yorum \\
\hline Timur Akkurt & İnsan & Gündem Haber Yorum \\
\hline Ünsal Ünlü & Haber & Gündem Haber Yorum
\end{tabular}

*Alfabetik olarak sıralanmıștır.

YouTube'un bünyesinde barındırdığı kanallara dair müzik, film, dizi, haber, eğlence gibi bir takım kategorileri bulunmaktadır. Bu çerçevede analiz edilen kanalların hangi kategoride yer aldığına baktığımızda yalnızca 5 kanalın 'haber' kategorisinde bulunduğu görülmektedir. Özışık, Yetkin ve Gürses'in kanalları herhangi bir kategoriye dâhil edilmemiştir. Timur Akkurt'un kanalı 'insan' kategorisinde yer alırken Mengü'nün kanalının 'film' kategorisinde bulunması ilginçtir. $\mathrm{Bu}$ durum YouTube'un veri düzenlemesi açısından problemli noktalarının olduğunu göstermektedir. Bununla birlikte kanalların daha profesyonel bir yapıda olması için kategorilerinin içerik yönünde sinıflandırılması önemlidir.

Kanalların ağırlıklı içeriklerine bakıldığında yoğun olarak gündem, haber ve yorum temalarının öne çıktığı görülmektedir. Bu kanalların genellikle gündemde olan ve ses getiren olaylara ilişkin canlı yayın yaptıkları ve yayınlarında sıklıkla konuk aldıkları görülmektedir. Yayınlar o günün çok konuşulan konuları üzerinden gerçekleştiğinde canlı sohbet bölümüne çok sayıda mesaj atılmaktadır. Dolayısıyla bu kanallarda çoğu zaman etkileşimin yüksek olduğu dikkat çekmektedir. Birçok kanalın yayın süresinde izleyicilerin yazdıklarını dikkate aldıkları ve izleyicilere cevap verdikleri de görülmektedir.

Tablo 7: İncelenen Kanalların Video İçerik Özellikleri*

\begin{tabular}{|c|c|c|c|c|}
\hline \multicolumn{5}{|c|}{ Video İçerik Özellikleri } \\
\hline Gazetecinin Adı & Jenerik & $\begin{array}{c}\text { KJ } \\
\text { Kullanımı }\end{array}$ & $\begin{array}{c}\text { Logo } \\
\text { Kullanımı }\end{array}$ & Görüntü \\
\hline Adem Özköse & Jenerik Yok & Yok & Yok & İç Mekân - Dış Mekân \\
\hline Can Ataklı & Jenerik Yok & Yok & Yok & $\begin{array}{l}\text { İç Mekân (Ofis) -Dış } \\
\text { Mekân (Sokak) }\end{array}$ \\
\hline Cüneyt Özdemir & Jenerik yok (Birkaç video hariç) & $\begin{array}{l}\text { Var (TV } \\
\text { formatında) }\end{array}$ & Yok & İç Mekân - Dış Mekân \\
\hline Mehmet Özışık & Bitiş & Var & Var & $\begin{array}{l}\text { İç Mekân (Stüdyo- } \\
\text { Ofis) }\end{array}$ \\
\hline Murat Yetkin & Jenerik Yok & Yok & Yok & $\begin{array}{l}\text { İç Mekân (Ofis- } \\
\text { Kütüphane) }\end{array}$ \\
\hline Nevşin Mengü & $\begin{array}{l}\text { Başlangıç ve Bitiş jeneriği var } \\
\text { (Genellikle geri sayım jeneriği) }\end{array}$ & $\begin{array}{l}\text { Var (TV } \\
\text { formatında) }\end{array}$ & Yok & $\begin{array}{l}\text { İç Mekân (Ofis-Ev) - } \\
\text { Diş Mekân }\end{array}$ \\
\hline Özlem Gürses & Jenerik Yok & $\begin{array}{l}\text { Var (TV } \\
\text { formatında) }\end{array}$ & $\begin{array}{l}\text { Var ( İç } \\
\text { Mekânda) }\end{array}$ & İç Mekân - Dış Mekân \\
\hline Ruşen Çakır & $\begin{array}{c}\text { Başlangıç ve Bitiş Jeneriği (TV } \\
\text { Programı gibi) }\end{array}$ & $\begin{array}{l}\text { Var (TV } \\
\text { formatında) }\end{array}$ & Var & İç Mekân (Stüdyo) \\
\hline Timur Akkurt & $\begin{array}{c}\text { Jenerik Yok } \\
\text { (Hep müzikle açıyor-kapatıyor }\end{array}$ & Var & Yok & $\begin{array}{c}\text { İç Mekân (Stüdyo)- Diş } \\
\text { Mekân }\end{array}$ \\
\hline
\end{tabular}


YouTube Ortamındaki Haberciliği Haritalandırmak: Gazetecilerin YouTube Haber Kanalları Üzerine Tanımlayıcı Bir Çalışma

\begin{tabular}{|c|c|c|c|c|}
\hline Ünsal Ünlü & $\begin{array}{c}\text { Jenerik Yok (Donuk kare ile } \\
\text { açılıș ve bitiș) }\end{array}$ & Yok & Yok & $\begin{array}{l}\text { İç Mekân (Kişisel } \\
\text { Stüdyo) }\end{array}$ \\
\hline
\end{tabular}

Tablo 7'de kanalların video içerik özellikleri gösterilmektedir. Buna göre ilk olarak jeneriğe baktığımızda çoğu kanalın jeneriğinin bulunmadığı görülmektedir. Jenerik kullanmak YouTube'un ilk zamanlarında oldukça yaygındı fakat son zamanlarda farklı kanal türlerinde de jenerik kullanılmamaya başlandı. YouTube'da izleyici yoğun bir video akışına dâhil olmaktadır. Hız son derece önemlidir. Bu bakımdan izleyicinin YouTube ortamında enformasyona hızlı bir şekilde ulaşmak istediği söylenebilir. Her videoda tekrar eden bir jeneriğin olması özellikle de haber teması söz konusu olduğunda istenmeyen bir özelliktir.

KJ kullanımı açısından kanallara bakıldığında 6 kanalın KJ kullandığı görülmektedir. Bu kanalların 4'ünde KJ'ler TV formatında kullanılmaktadır. Bu kanallardan Özdemir, Mengü ve Çakır abone sayısı en yüksek kanallardır. Dolayısıyla izleyici açısından profesyonelliğin önemli olduğu çıkarımında bulunulabilir. Kanalların çoğunda logo kullanılmadığı görülmektedir. Bu durum ise kanalların kurumsal değil bireysel kimlik yapılanmasına önem verdikleri şeklinde yorumlanabilir. Kanallara genel olarak bakıldığında yalnızca iç mekânı kullanan 4, hem iç hem dış mekânı kullanan 6 kanal olduğu görülmektedir. Mekân kullanımı açısından da gazetecilerin geleneksel medyaya göre oldukça özgür hareket ettikleri söylenebilir

Tablo 8: İncelenen Kanalların Yayıncılık Biçimleri*

\begin{tabular}{lc}
\hline \multicolumn{1}{c}{ Gazetecinin Adı } & Yayıncılık Biçimleri \\
\hline Adem Özköse & Canlı - Kayıt (Kayıt Ağırlıklı) \\
\hline Can Ataklı & Canlı - Kayıt \\
\hline Cüneyt Özdemir & Canlı - Kayıt (Canlı Ağırlıklı) \\
\hline Mehmet Özıșık & Kayıt (İlk Gösterim) \\
\hline Murat Yetkin & Kayıt \\
\hline Nevşin Mengü & Canlı - Kayıt (Canlı Ağırlıklı) \\
\hline Özlem Gürses & Canlı - Kayılt (Canlı Ağırlıklı) \\
\hline Ruşen Çakır & Canlı - Kayıt (Canlı Ağırlıklı) \\
\hline Timur Akkurt & Canlı - Kayıt \\
\hline Ünsal Ünlü & Canlı \\
\hline *Alfabetik olarak sıralanmıștır.
\end{tabular}

Tablo 8'de kanalların yayıncılık biçimleri incelendiğinde canlı yayınların ağırlıkta olduğu görülmektedir. Gazetecilerin çoğu hem kayıt hem de canlı yayını tercih ederken Yetkin ve Özışık yalnızca kayıt, Ünlü yalnızca canlı yayın biçimini tercih etmektedir. Yayıncılık biçimleri göz önünde bulundurulduğunda YouTube'un canlı yayın özelliğinin olması habercilik açsından son derece önemlidir. Bununla birlikte teknolojik gelişmelerin canlı yayın olanağını çok fazla kolaylaştırdığı da dikkate değer bir gerçektir.

Tablo 9: Kanalların En Fazla İzlenen Videoları İle En Fazla Yorum Yapılan Videoları ve Türleri* 


\begin{tabular}{|c|c|c|c|c|}
\hline $\begin{array}{l}\text { Gazetecinin } \\
\text { Adı }\end{array}$ & $\begin{array}{c}\text { En Fazla İzlenen } \\
\text { Video }\end{array}$ & $\begin{array}{l}\text { En Fazla İzlenen } \\
\text { Videonun Haber } \\
\text { Kategorisi/Türü }\end{array}$ & $\begin{array}{c}\text { En Fazla Yorum Yapılan } \\
\text { Video }\end{array}$ & $\begin{array}{c}\text { En Fazla Yorum } \\
\text { Yapılan Video } \\
\text { Kategorisi / Türü }\end{array}$ \\
\hline $\begin{array}{l}\text { Adem } \\
\text { Özköse }\end{array}$ & $\begin{array}{l}\text { Hayatı İslam'la Değişen } \\
\text { Eski PKKlı Genç / } \\
\text { İçimizden Biri \#3 } \\
\mathbf{9 6 9} \text { Bin }\end{array}$ & Röportaj & $\begin{array}{l}\text { Çin Zindanlarında Kalan } \\
\text { Doğu Türkistanlı Müslüman } \\
\text { Türk - Abdulhaber Recep / } \\
\text { Içcimizden Biri \#4 } \\
\mathbf{5 . 7 2 4}\end{array}$ & Röportaj \\
\hline Can Ataklı & $\begin{array}{l}\text { Peker'den inanılmaz } \\
\text { açıklama } 385 \text { Bin }\end{array}$ & $\begin{array}{l}\text { Haber /Gündem/ } \\
\text { Yorum }\end{array}$ & $\begin{array}{l}\text { Mansur Yavaş ve Ekrem } \\
\text { İmamoğlu doğru adaylar } \\
\text { değil } \\
\mathbf{2 . 9 7 9}\end{array}$ & $\begin{array}{l}\text { Gündem/ } \\
\text { Yorum }\end{array}$ \\
\hline $\begin{array}{l}\text { Cüneyt } \\
\text { Özdemir }\end{array}$ & $\begin{array}{l}\text { Başbakan Recep } \\
\text { Tayyip Erdoğan'ın } \\
\text { kendisine açılan } \\
\text { davalar hakkında ne } \\
\text { düşünüyor? 4,3 Milyon }\end{array}$ & Haber/Röportaj & $\begin{array}{l}\text { ALİ BABACAN CÜNEYT } \\
\text { ÖZDEMIR'IN } \\
\text { SORULARINI } \\
\text { YANITLIYOR } \\
\mathbf{7 . 5 8 7}\end{array}$ & Röportaj \\
\hline $\begin{array}{l}\text { Mehmet } \\
\text { Özışık }\end{array}$ & $\begin{array}{l}\text { PEÇEYLE ALAY } \\
\text { EDEN HÜLYA } \\
\text { AVŞAR'A TOKAT } \\
\text { GİḂ CEVAP (Mehmet } \\
\text { Özış1k) } \\
\mathbf{1 8 9} \text { Bin }\end{array}$ & $\begin{array}{l}\text { Haber /Gündem/ } \\
\text { Yorum }\end{array}$ & $\begin{array}{l}\text { CHP'LILER DEVLETİ } \\
\text { GÖREVE ÇAĞIRIYOR: } \\
\text { BİZE KAYYUM ATAYIN! } \\
\mathbf{2 . 1 4 7}\end{array}$ & Gündem/ Yorum \\
\hline $\begin{array}{l}\text { Murat } \\
\text { Yetkin }\end{array}$ & $\begin{array}{l}\text { Peker videoları } \\
\text { Erdoğan'ın "mıntıka } \\
\text { temizliğini" } \\
\text { kolaylaştırıyor. } \\
\text { 151 Bin }\end{array}$ & $\begin{array}{l}\text { Haber /Gündem/ } \\
\text { Yorum }\end{array}$ & $\begin{array}{l}13 \text { tutsak şehit: Gara'da } \\
\text { neler oldu? } \\
\mathbf{4 3 3}\end{array}$ & $\begin{array}{l}\text { Gündem/ } \\
\text { Yorum }\end{array}$ \\
\hline $\begin{array}{l}\text { Nevşin } \\
\text { Mengü }\end{array}$ & $\begin{array}{l}\text { Efsane Geri Vitesler } \\
1 \text { Milyon }\end{array}$ & $\begin{array}{l}\text { Haber /Analiz/ } \\
\text { Yorum }\end{array}$ & $\begin{array}{l}\text { Efsane Geri Vitesler } \\
\mathbf{6 . 8 3 3}\end{array}$ & Analiz/Yorum \\
\hline $\begin{array}{l}\text { Özlem } \\
\text { Gürses }\end{array}$ & $\begin{array}{l}\text { GÜLNAZ ŞIRINGA } \\
\text { HADİ ÖZIŞIK'I } \\
\text { ANLATIYOR! } \\
\mathbf{3 1 6} \text { Bin }\end{array}$ & $\begin{array}{l}\text { Haber /Gündem/ } \\
\text { Yorum }\end{array}$ & $\begin{array}{l}\text { BUYRUN SİE KİNDAR } \\
\text { NESIL :))) } \\
\mathbf{2 . 5 1 3}\end{array}$ & $\begin{array}{l}\text { Gündem/ } \\
\text { Yorum }\end{array}$ \\
\hline $\begin{array}{l}\text { Ruşen } \\
\text { Çakır }\end{array}$ & $\begin{array}{l}\text { Levent Gültekin: } \\
\text { "Türkiye'yi üç kişi } \\
\text { yönetiyor. Geri kalan } \\
\text { herkes figüran" } \\
\text { 645 Bin }\end{array}$ & $\begin{array}{l}\text { Haber /Gündem/ } \\
\text { Yorum }\end{array}$ & $\begin{array}{l}\text { Sedat Peker'in yedinci } \\
\text { videosu: Uyuyan dev } \\
\text { uyandırılınca... } \mathbf{1 0 0 3}\end{array}$ & $\begin{array}{l}\text { Gündem/ } \\
\text { Yorum }\end{array}$ \\
\hline $\begin{array}{l}\text { Timur } \\
\text { Akkurt }\end{array}$ & $\begin{array}{l}\text { CEM YILMAZ'IN İLK } \\
\text { GÖSTERİII - LEMAN } \\
\text { KÜLTÜR } 1995 \\
\mathbf{9 6 5} \text { Bin }\end{array}$ & Vlog / Magazin & $\begin{array}{l}\text { İSTANBUL İZMİR } \\
\text { OTOYOLU KAÇ PARA? } \\
\text { GERÇEKTEN 3.5 SAAT } \\
\text { Mİ? (OTOYOL TESTİ) } \\
\mathbf{2 . 9 3 5}\end{array}$ & Vlog \\
\hline Ünsal Ünlü & $\begin{array}{l}\text { Miting meydanları ilk } \\
\text { kez AKP'yi mutlu } \\
\text { etmiyor. } \\
\mathbf{1 0 3} \text { Bin } \\
\end{array}$ & $\begin{array}{l}\text { Haber /Gündem/ } \\
\text { Yorum }\end{array}$ & $\begin{array}{l}\text { Miting meydanları ilk kez } \\
\text { AKP'yi mutlu etmiyor. } \\
\text { 330 }\end{array}$ & Gündem/ Yorum \\
\hline
\end{tabular}

*Alfabetik olarak sıralanmıştır.

Tablo 9'da analiz edilen kanalların en fazla izlenen videosu ile en fazla yorum alan videosuna dair bilgilere yer verilmektedir. Buna göre izlenme sayısı ile yorum sayısı arasında doğru orantılı bir ilişki olmadığı görülmektedir. Diğer bir ifadeyle en çok izlenen videolar ile en fazla yorum alan videolar aynı değildir. Fakat Nevşin Mengü'nün kanalı bu konuda istisnadır. Mengü'nün en çok izlenen ve en çok yorum alan videosu aynıdır. Bununla birlikte en fazla izlenen videoların içerikleri incelendiğinde 3 videonun Sedat Peker ile ilgili, 3 videonun Recep Tayyip Erdoğan ile ilgili olduğu görülmektedir. En fazla yorum alan videolara bakıldığında ise siyasi partiler ve siyasi kişiler ile ilgili 
YouTube Ortamındaki Haberciliği Haritalandırmak: Gazetecilerin YouTube Haber Kanalları Üzerine Tanımlayıcı Bir Çalışma

haberler dikkat çekmektedir. Kanallar birbiri ile kıyaslandığında en fazla izlenen videonun 4,3 Milyon ile Özdemir'e ait olduğu görülmektedir. Bu videonun konusu Recep Tayyip Erdoğan'dır. Aynı şekilde en fazla yorum alan video da Özdemir'e aittir. $\mathrm{Bu}$ video ise Ali Babacan ile yapılan röportajı içermektedir. Özetle en fazla izlenen ve en fazla yorum yapılan videoların konuları incelendiğinde siyasi konuların ağırlıklı olduğu görülmektedir.

\section{Sonuç}

YouTube, hem sosyal paylaşım ağı hem de arama motoru işlevi gören en büyük video paylaşım platformudur. YouTube ortamında müzikten sinemaya, çocuk kanallarından kişisel vloglara kadar çeşitli içeriklerde yayınlar yapılmaktadır. YouTube'da giderek popüler hale gelen yayıncılık türlerinden biri de haberdir. YouTube'daki habercilik üç farklı şekilde sınıflandırılabilmektedir. Bu sınıflandırma geleneksel yayın organlarına ait YouTube haber kanalları, dijital haber kanallarına ait YouTube haber kanalları ve gazetecilerin bireysel YouTube haber kanalları şeklinde ortaya çıkmaktadır.

$\mathrm{Bu}$ çalışmada YouTube ortamında etkin içerik üretiminde bulunan gazetecilerin YouTube haber kanallarına odaklanılmıştır. Bu çerçevede belirlenen araştırma soruları ekseninde kategoriler oluşturularak araştırmanın örneklemi içerisinde yer alan kanallar detaylı bir şekilde analiz edilmiştir. Belirli kıstaslar üzerinden gerçekleştirilen taramalar sonucu örnekleme uyan toplam 10 YouTube haber kanalı olduğu tespit edilmiştir. Gazeteciler haber kanallarında kendi isimlerini kullanmaktadır. Bu kanal sahiplerinin geleneksel medyada uzun yıllar çalışmış gazetecilerden oluştuğu, ayrıca gazete ve televizyon kökenli oldukları da tespitler arasındadır. YouTube'un 'hakkında' sekmesinde ise kanal sahiplerinin birçoğunun kendisini gazeteci olarak tanımlamaktadır. Kanalların açılış tarihleri ile içerik üretim tarihleri karşılaştırıldığında birçok kanalın açılış tarihinden çok sonra yayın yapmaya başladığ 1 görülmüştür.

Çalışma kapsamında analiz edilen kanallar abone sayısı, video sayısı ve kanal görüntüleme sayısı çerçevesinde karşılaştırıldığında diğer kanallara göre rakamsal değerler açısından oldukça önde bulunan kanalın Cüneyt Özdemir'e ait olduğu görülmüştür. Ayrıca yayın sıklığı bağlamında son bir haftada 12 video ile en fazla video yayınlayan gazeteci de Özdemir'dir. Çakır 11 video ile ikinci sırada, Gürses 10 video ile üçüncü sırada yer almaktadır. Kanallar içerisinde 5 hesabın doğrulanmış olduğu görülmüştür. Çoğu gazetecinin katıl butonunu aktif hale getirdiği tespit edilmiştir. Bununla birlikte kanalların kazançlarına ilişkin veriler YouTube'un gazeteciler için yeni bir iş kapısı olduğunun göstergesi niteliğindedir.

YouTube'daki habercilik faaliyetleri standart bir süre ve programa bağlı kalınarak yapılan televizyon haberciliğinin oldukça dışındadır. Videolar incelendiğinde standart bir video süresinin olmadığı görülmüştür. İncelenen kanalların yarısının haber kategorisinde yer aldığı tespit edilmiştir. Kanal içerikleri ise yoğun olarak gündem, haber ve yorumdan oluşmaktadır. Kanalların genellikle gündemde olan olaylara ilişkin canlı yayın yaptıkları ve yayınlarında sıklıkla konuk aldıkları görülmektedir. Kanalların çoğunda jenerik kullanılmamaktadır. KJ kullanımı açısından kanallara bakıldığında ise 
6 kanal KJ kullanmaktadır. Bu kanalların 4'ünde KJ'lerin TV formatında olduğu tespit edilmiştir. Kanalların çoğunda logo kullanılmadığı görülmektedir. Kanalların yayıncılık biçimleri incelendiğinde canlı yayınların ağırlıkta olması dikkat çekmektedir.

Analizler sonucu kanalların en çok izlenen videoları ile en fazla yorum alan videolarının aynı olmadığı görülmüştür. Yalnızca Mengü’nün en çok izlenen ve en çok yorum alan videosu aynıdır. Ayrıca en fazla izlenen videoların içeriklerine bakıldığında 3 videonun Sedat Peker ile ilgili, 3 videonun ise Recep Tayyip Erdoğan ile ilgili olması dikkat çekicidir. En fazla yorum alan videolarda ise siyasi partiler ve siyasi kişiler ile ilgili haberler yoğunluktadır. En fazla izlenen video Özdemir'in 'Başbakan Recep Tayyip Erdoğan'ın kendisine açılan davalar hakkında ne düşünüyor?' isimli ve 4,3 Milyon izlemeye ulaşmış olan videosudur. Diğer taraftan en fazla yorum alan video da Özdemir'e aittir. Bu videonun konusunu ise Ali Babacan ile yapılan röportaj oluşturmaktadır.

Genel olarak tüm tespitler göz önünde bulundurulduğunda gazeteci, YouTube'da geleneksel medyaya göre pek çok açıdan daha bağımsızdır. Daha açık bir ifadeyle, yapılan analizler sonucu gazetecinin içerik, yayın sıklığı, yayın süresi, yayın tarihi, yayın saati, mekân, video içerik özellikleri, yayıncılık türü gibi açılardan daha özgür olduğu, kullanıcı ile etkileşim, canlı yayın gibi olanaklar açısından YouTube'un haberciliğe son derece avantajlı bir ortam sunduğu tespit edilmiş̧ir. Ayrıca kanallar üzerinde yapılan incelemeler dikkate alındığında YouTube ortamında gazetecinin haberi aktaran kişinin ötesinde bir aktör olarak ortaya çıktığı soncuna ulaşılmıştır.

\section{Kaynaklar}

Antony, M. G., ve Thomas, R. J. (2010). 'This is citizen journalism at its finest': YouTube and the public sphere in the Oscar Grant shooting incident. New Media ve Society, 12(8), 1280-1296.

Bardoel, J., ve Deuze, M. (2001). Network journalism': converging competencies of old and new media professionals. Australian Journalism Review, 23(2), 91-103.

Benkler, Y., Faris, R., ve Roberts, H. (2018). Network propaganda: manipulation, disinformation, and radicalization in American politics. Oxford: Oxford University Press.

Birsen, H. (2005). İnternet haberciliği ve aktif izlerkitle ilişkisi çerçevesinde etik tartışmalar. Selçuk Iletetisim, 3(4), 68-79.

Buadit, K., ve Laophairot, P. (2021). Present fake news by the mass media in public attitudes and ethics in the digital media that affects reciver in Nakhon Sawan area. Journal of Legal Entity Management and Local Innovation, 7(4), 217-227.

Bulunmaz, B. (2011). İnternet gazeteciliğinin medya dünyası içindeki rolü ve ekonomik boyutları. Marmara İletişim Dergisi, (18), 27-46. 
YouTube Ortamındaki Haberciliği Haritalandırmak: Gazetecilerin YouTube Haber Kanalları Üzerine Tanımlayıcı Bir Çalışma

Bulut, S. (2020). Egemen söylemin kıyısındakiler: alternatif bir platform olarak Youtube'da gazetecilik ve gazeteciler üzerine bir inceleme. Erciyes İletişim Dergisi, 7(2), 727-748.

Bulut, S. (2020). Yazılı basın sınır ötesinde: içeriğin kâğıttan videoya dönüşümü ve gazetelerin Youtube platformundaki habercilik deneyimleri. The Turkish Online Journal Of Design Art And Communication, 10(4), 555-572.

Burgess, J. (2011) YouTube. In Meyer, L H (Ed.) Oxford Bibliographies Online. Oxford University Press, United Kingdom.

Chan, M. (2017). Media use and the social identity model of collective action: examining the roles of online alternative news and social media news. Journalism ve Mass Communication Quarterly, 94(3), 663-681.

Chau, C. (2010). YouTube as a participatory culture. New directions for youth development, Wiley. (128), 65-74.

Çapl1, Bülent (2002). Medya ve Etik. İmge Kitabevi.

Çevikel, T. (2004). Türkçe haber siteleri ve Türkiye'de internet gazeteciliğginin gelişimini sınırlayan faktörler. Galatasaray Üniversitesi İletişim Dergisi, (1). 147-163

Çevikel, T. (2015). İnternet gazetecilerinin haber medyasında kullanıcı katılımına ilişkin görüss ve tutumlar1. Folklor/Edebiyat, 21(83), 217-234.

Dağtaş, E., ve Şirvanlı, T. (2020). Anaakım medya karşısında alternatif medya yayıncılığı: Ünsal Ünlü’nün “Patronsuz” programı örneği. Intermedia International E-journal, 7(13), 317-337.

Datareportal (2021). Digital 2021: Local Country Headlines. Erişim adresi: https://datareportal.com/reports/digital-2021-local-countryheadlines?utm_source=Reportsveutm_medium $=$ PDFveutm_campaign $=$ Digital_202 1veutm_content=Single_Report_Promo_Slide, Erişim tarihi: 20.06.2021.

Datareportal (2021). Digital 2021: Global Overview Report. Erişim adresi: https://datareportal.com/reports/digital-2021-global-overviewreport?utm_source=Reportsveutm_medium=PDFveutm_campaign=Digital_2021ve utm_content=Dual_Report_Promo_Slide, Erişism tarihi:20.06.2021.

Demir, Y., ve Ayhan, B. (2020). Sosyal medyanın gündem belirleyicileri: Twitter'da gündem belirleme süreci üzerine bir sosyal ağ analizi. İletişim Kuram ve Araştırma Dergisi, (51), 1-19.

Deuze, M., ve Yeshua, D. (2001). "Online journalists face new ethical dilemmas: lessons from The Netherlands.” Journal of Mass Media Ethics, 16(4):273-292. 
Djerf-Pierre, M., Lindgren, M., ve Budinski, M. A. (2019). The role of journalism on YouTube: audience engagement with" Superbug" reporting. Media and Communication, 7(1), 235-247.

Duman, K. (2018). Arama motorları ve internet haberciliğine etkileri: Türk internet haber medyası örneği. Selçuk İletişim, 11(1), 257-287.

Fletcher, R., ve Nielsen, R. K. (2018). Are people incidentally exposed to news on social media? A comparative analysis. New Media ve Society, 20(7), 2450-2468.

Friend, C., ve Singer, J. (2015). Online journalism ethics: traditions and transitions. Routledge.

Geray, H. (2014). Toplumsal araştırmalarda nicel ve nitel yöntemlere giriş. Umuttepe Yayınları.

Geray, H., ve Aydoğan, A. (2010). Yeni iletişim teknolojileri ve etik. Bülent Çaplı ve Hakan Tuncel (der.), Televizyon Haberciliğinde Etik. Fersa Matbaacılı.

Gürcan, H. İ. İnternet gazeteleri ile klasik gazeteler arasında karşılaştırma, http://www.dorduncukuvvetmedya.com/arastirma/internetgaz/internetgaz4.htm, 15.5.2021.

He, L., Han, C., Mukherjee, A., Obradovic, Z., ve Dragut, E. (2020). On the dynamics of user engagement in news comment media. Wiley Interdisciplinary Reviews: Data Mining and Knowledge Discovery, 10(1), e1342.

Heinonen, A. (1999). Journalism in the age of the net. Acta Universitatis Tamperensis.

Holt, K., Ustad Figenschou, T., ve Frischlich, L. (2019). Key dimensions of alternative news media. Digital Journalism, 7(7), 860-869.

İşliyen, F. Ş. (2021). Hakikat sonrası çağda parodi haberlerin yükselişi ve etik sorunlar. İnönü Üniversitesi İletişim Fakültesi Elektronik Dergisi (İnif E-Dergi), 6(1), 222238.

Kıyan, Z., ve Törenli, N. (2018). Sosyal medyanın gazetecilikteki rolü: Türkiye'deki haber kuruluşları üzerine bir inceleme. Gaziantep University Journal Of Social Sciences, 17(1).

Korkmaz, A. (2009). İnternet gazeteciliğinin kamuoyu oluşumuna etkisi. Erciyes İletişim Dergisi, 1(2). 6-19.

Mesutoğlu, N. (2020). Yeni medya haber okuma alışkanlığı ve yeni okur tipolojisinde farklılıklar. Ege Üniversitesi İletişim Fakültesi Medya ve Illetişim Araştırmaları Hakemli E-Dergisi, (7), 31-58.

Nygaard, S. (2019). The Appearance of objectivity: how immigration-critical alternative media report the news. Journalism Practice, 13(10), 1147-1163. 
YouTube Ortamındaki Haberciliği Haritalandırmak: Gazetecilerin YouTube Haber Kanalları Üzerine Tanımlayıcı Bir Çalışma

O'sullivan, J., ve Heinonen, A. (2008). Old values, new media: journalism role perceptions in a changing world. Journalism Practice, 2(3), 357-371.

Öztermiyeci, M. (2017). İnternet gazeteciliği geleneksel gazeteciliğe karşı. Türk Dünyası Araştırmaları, 116(228), 171-190.

Paulussen, S., ve Harder, R. A. (2014). Social media references in newspapers: Facebook, Twitter and YouTube as sources in newspaper journalism. Journalism practice, $8(5), 542-551$.

Pavlik, J. (2001). Journalism and new media. Columbia University Press.

Peer, L., ve Ksiazek, T. B. (2011). YouTube and the challenge to journalism: new standards for news videos online. Journalism Studies, 12(1), 45-63.

Poell, T., ve Borra, E. (2012). Twitter, YouTube, and Flickr as platforms of alternative journalism: The social media account of the 2010 Toronto G20 protests. Journalism, 13(6), 695-713.

Tandoc Jr, E. C., ve Thomas, R. J. (2015). The ethics of web analytics: Implications of using audience metrics in news construction. Digital journalism, 3(2), 243-258.

Tok. İ. (2021). Ulusal gazetelerin bir haber mecrası olarak Youtube'u kullanma biçimlerinin incelenmesi. Selçuk İletişim, 14(1), 306-335.

Umur, I., ve Koz, K. A. (2014). Çöp yığınlarında haber aramak: internet gazeteciliği üzerine bir çalışma. Humanities Sciences, 9(2), 27-43.

Wearesocial. (2021). Digital 2021. Erişim adresi: https://wearesocial.com/digital-2021, Erişim tarihi: 21.06.2021.

Webolizma. (2021). Hootsuite ve We Are Social 2021 Dijital Türkiye Raporu. Erişim adresi: https://www.webolizma.com/hootsuite-ve-we-are-social-2021-dijitalturkiye-raporu/\#2020_Yilinda_Neleri_Aradik, Erişim tarihi: 15.05.2021.

YouTube, (2021). About. Erişim Adresi: https://www.youtube.com/intl/tr/about/, Erişim tarihi: 10.05.2021.

Yurdigül, Y., ve Zinderen, İ. E. (2012). Yeni medyada haber dili (Ayşe Paşali olayi üzerinden geleneksel medya ve internet haberciliği karşılaştırması). The Turkish Online Journal of Design Art and Communication, 2(3), 81-9 